\title{
'Barbara Bush' Bluebonnet (Lupinus texensis Hook.)
}

\author{
Jerry M. Parsons ${ }^{1}$, Tim D. Davis ${ }^{2}$, Steven W. George ${ }^{2}$, and \\ Wayne A. Mackay ${ }^{3}$ \\ Texas Agricultural Extension Service, 1143 Coliseum Road, San Antonio, \\ TX 78219
}

Additional index words. bedding plant, flower color, lupine, ornamentals breeding

Bluebonnet, the Texas state flower, encompasses all six of the Lupinus species native to Texas. The most popular and widespread bluebonnet, Lupinus texensis, is a winter annual that produces violet-blue (violet-blue group 96A, Royal Horticultural Society Colour Chart) [Royal Horticultural Society (RHS), 1982] racemes in early to mid-spring and is predominately self-pollinating. This species is used widely as floral displays along roadsides throughout much of the state (Andrews, 1986). Although pink and white variants exist in native populations, they are rare. Thus, a breeding project was initiated in 1985 to develop bluebonnets with novel flower colors for use as bedding plants. 'Abbott Pink' was the first seed-propagated cultivar to be released from this project (Parsons and Davis, 1993). Subsequently, we have used recurrent phenotypic selection for lavender flower color to develop 'Barbara Bush'. This cultivar is intended for use as a bedding plant and is named after the former First Lady and wife of former U.S. President George Bush. The ceremonial naming of the cultivar was held at Texas A\&M Univ. on 9 Mar. 1994 (see cover photo).

\section{Origin}

Seed was collected by J.M.P. in Spring 1987 from a small patch of lavender-flowered bluebonnets that appeared in a seed production field of pink-flowered plants (the progenitors of 'Abbott Pink') in LaPryor, located in south-central Texas. To our knowledge, this

\footnotetext{
Received for publication 13 June 1994. Accepted for publication 15 Aug. 1994. The cost of publishing this paper was defrayed in part by the payment of page charges. Under postal regulations, this paper therefore must be hereby marked advertisement solely to indicate this fact.

${ }^{1}$ Professor.

${ }^{2}$ Associate Professor, Texas A\&M Univ. Research and Extension Center, 17360 Coit Rd., Dallas, TX 75252-6599.

${ }^{3}$ Assistant Professor, Texas A\&M Univ. Research Center, 1380 A\&M Circle, El Paso, TX 79927.
}

novel flower color had never been previously recorded. The seed from these specimens was planted in Fall 1987 and, the following spring, produced a population containing $\approx 80 \%$ lavender-flowered plants that were allowed to mate randomly. The remaining $20 \%$ of the plants had violet-blue or pink flowers and were rogued as soon as their color was visible. Seed was collected in Spring 1988 from the remaining lavender-flowered plants and planted out in the fall. Recurrent phenotypic selection for lavender flowers was repeated for two more years (one cycle per year) until a pure lavender-shaded population was obtained. This line has been grown in isolation for two additional years and is now being released as 'Barbara Bush'. Seed collected from 'Barbara Bush' will remain pure if plantings are isolated from other bluebonnets.

\section{Description}

Young plants form a dense rosette in the fall and then bloom the following March or April. The bloom period is 3 to 5 weeks. The plant produces 100 to 200 racemes $/ \mathrm{m}^{2}$ ground surface. The racemes (see cover photo), which are mildly fragrant, are shades of lavender (RHS violet group 84C-93B), 8-12 cm long, and each contains 25-40 florets. The last racemes produced during the season tend to be shorter than the first ones. Each floret is $1-2 \mathrm{~cm}$ long and has a 3- to 6-mm-wide white banner spot in the center of the banner petal. This spot often turns to reddish purple (RHS red-purple group $61 \mathrm{AB}$ ) with age, but the florets sometimes shrivel before the color change occurs. Pedicels are 6-12 mm long, and flower spike stems are $2-4 \mathrm{~mm}$ in diameter. At full bloom, the plants are $30-50 \mathrm{~cm}$ tall, $50-70 \mathrm{~cm}$ in diameter, and have a mounded form. The foliage is yellow-green (RHS yellow-green group 146B) and is composed of alternate, palmately compound leaves generally with five leaflets (occasionally with six). Each individual leaflet is oblanceolate, $3-5 \mathrm{~cm}$ long, and $12-16 \mathrm{~mm}$ wide at the widest position. Petioles are $4-6 \mathrm{~cm}$ long. Pods $(30-50 \mathrm{~mm}$ long and 6-10 $\mathrm{mm}$ wide) become visible about one month after anthesis, are densely pubescent, and contain four to seven seeds each. Weight per 100 seeds is $\approx 3.5 \mathrm{~g}$. Seeds are light brown, occasionally speckled with black.

\section{Cultivation}

Seed must be scarified to obtain optimal germination(Davis et al., 1991). Concentrated sulfuric acid applied for 30-60 min is generally satisfactory for scarification. Irrigation or rainfall is needed to induce germination, but once plants are established, they require little additional irrigation under central Texas climatic conditions. The plants overwinter in U.S. Dept. of Agriculture hardiness zones 8-10 (U.S. Dept. of Agriculture, 1990) and often survive winter in zone 7. 'Barbara Bush' for bedding plant production grows well in most soilless media. However, the plants must be maintained under well-drained conditions to avoid problems with damping off and other as yet unidentified root rots. Chilling is not required for flowering.

\section{Performance}

Except for having a different flower color, the garden performance of 'Barbara Bush' is nearly identical to the native violet-blue bluebonnet and the previously released 'Abbott Pink' (Parsons and Davis, 1993). Plants have been grown from seed in the greenhouse and successfully transplanted outdoors at the following diverse Texas locations: San Antonio (4 years at several sites); Dallas (2 years); LaPryor (4 years); Center (2 years); El Paso (1 year). Comparative trials at these locations revealed no differences in garden performance between 'Barbara Bush' and the native violetblue bluebonnet.

\section{Availability}

'Barbara Bush' seed can be purchased from Texas Seed Co., P.O. Drawer 599, Kenedy, TX 78119-0599.

\section{Literature Cited}

Andrews, J. 1986. The Texas bluebonnet. Univ. of Texas Press, Austin

Davis, T.D., S.W. George, A. Upadhyaya, and J. Parsons. 1991. Improvement of seedling emergence of Lupinus texensis Hook. following seed scarification treatments. J. Environ. Hort. 9:1721.

Parsons, J.M. and T.D. Davis. 1993. 'Abbott Pink' bluebonnet (Lupinus texensis Hook.) HortScience 28:65-66.

Royal Horticultural Society. 1982. Royal Horticultural Society colour chart. Royal Horticultural Society, London.

U.S. Dept. of Agriculture. 1990. Plant hardiness zone map. Misc. Publ. 1475, Agr. Res. Serv., Washington, D.C. 